\title{
KNIHOVNY V ČESKÉ REPUBLICE V DOBĚ PANDEMIE COVID-19: VÝSLEDKY KVALITATIVNÍ STUDIE
}

\section{CZECH LIBRARIES DURING THE COVID-19 PANDEMIC: QUALITATIVE STUDY RESULTS}

\author{
Adéla Jarolímková, Barbora Drobíková \\ Univerzita Karlova, Filozofická fakulta, Ústav informačních studií a knihovnictví
}

\begin{abstract}
Abstrakt
Účel - Příspěvek představuje výsledky kvalitativní studie zaměřené na situaci českých knihoven v období pandemie Covid-19, a sice na jaře a na podzim roku 2020, doplněný přehledem protiepidemických opatření týkajících se provozu knihoven. Rovněž stručně shrnuje dosud publikovanou českou i zahraniční literaturu k tématu.
\end{abstract}

Design/metodologie/přístup - Data byla získána formou polostrukturovaných rozhovorů s cílem zjistit, jak se proměnily služby knihoven $\mathrm{v}$ důsledku epidemiologických opatření, včetně srovnání jarní a podzimní vlny. Otázky se týkaly fyzických i elektronických fondů a s nimi spojených služeb, vzdělávací činnosti, komunitní role a propagace knihovny. Informace o protiepidemických opatřeních byly získány analýzou vládních opatření a elektronického archivu konference Knihovna.

Výsledky - Pro knihovny znamenalo jarní uzavření šok, následné rozvolňování pak především chaos a rychlé změny, kdy bylo třeba improvizovat především ve výpůjčních službách, protiepidemická opatření se ve velkém dotkla také pořádání vzdělávacích a komunitních akcí, které se částečně přesunuly online. Knihovny se musely vyrovnat s potřebou jiné organizace práce, v době uzavření pak s nalezením náhradních činností. Nejvíce byly opatřeními postiženy výpůjční služby, počet fyzických výpůjček klesl, naopak využívání elektronických zdrojů stouplo, ačkoliv ne vždy se jednalo o významný nárůst. Mezi zmiňovaná pozitiva patř̌i zejména důležitost knihoven, mnohdy nepostradatelnost, zájem čtenářù, změny v uvažování, které vedly k přehodnocení některých procesů, rozvoj digitálních služeb či ověření reakce a adaptace na krizovou situaci.

Originalita/hodnota - Ačkoliv byly již publikovány články o českých knihovnách v době pandemie, zejména formou kazuistik o jednotlivých knihovnách či regionech, ale i obsahující výsledky dílčích dotazníkových šetření, kvalitativní studie knihoven dosud publikována nebyla.

Klíčová slova: Covid-19, knihovny, kvalitativní výzkum, služby knihoven, protipandemická opatření 


\section{Abstract}

Purpose - The paper presents the results of a qualitative study focused on the Czech libraries' situation during the Covid-19 pandemic, namely in the spring and autumn of 2020, supplemented by an overview of anti-epidemic measures concerning the libraries. It also briefly summarizes the Czech and foreign literature on the topic published so far.

Design/Methodology/Approach - Data were obtained through semi-structured interviews with the aim to find out how the anti-epidemic measures influenced library services, including a comparison of the spring and autumn waves. The questions concerned print and electronic holdings and related services, educational activities, community role and library promotion. Information on anti-epidemic measures was obtained through an analysis of government documents and the electronic archive of the e-mail conference „Knihovna”.

Results - For libraries, the spring closure meant a shock, and the subsequent loosening of measures meant chaos and rapid changes, it was necessary to improvise, especially in lending services; antiepidemic measures also greatly affected the organization of educational and community events, which partially moved online. Libraries had to cope with the need for a different work organization, and at the time of closure they had to find alternative activities. The number of physical loans decreased, while the use of electronic resources increased, although this was not always a significant increase. Some positives were mentioned including the importance of libraries, the interest of readers, changes in thinking that led to the reassessment of certain processes, the development of digital services or verification of the response and adaptation to a crisis.

Originality/Value - Although articles on Czech libraries during the pandemic have been already published, mainly in the form of case studies on individual libraries or regions, but also containing the results of partial questionnaire surveys, a qualitative study of libraries has not yet appeared.

Keywords: Covid-19, libraries, qualitative study, library services, anti-pandemic measures 


\section{Úvod}

Pandemie Covid-19 výrazně ovlivnila chod celé společnosti a zasáhla do činnosti knihoven v míree, kterou jsme si nikdy předtím nedovedli představit. Článek představuje výsledky kvalitativní studie, která se zaměřila na situaci v českých knihovnách na jaře a na podzim roku 2020, tedy po vypuknutí pandemie a v její druhé vlně, doplněné o přehled jednotlivých opatření zaváděných v průběhu roku 2020 a také o stručný přehled literatury k tématu. Data byla získána z rozhovorů vedených studenty v rámci jednoho z předmětů vyučovaných na Ústavu informačních studií a knihovnictví.

Na tomto místě bychom rádi poděkovali všem ochotným účastníkům a účastnicím výzkumných rozhovorů, bez nichž by níže zveřejněné výsledky nebylo možné získat.

\section{Přehled literatury $\mathbf{k}$ tématu}

V zahraničí byla již v průběhu roku 2020 a následně i v letošním roce publikována řada článků a studií zabývajících se reakcí knihoven na pandemii Covid-19. V některých případech se jednalo spíše o prezentaci názorů na roli knihoven v pandemii či př́ímo rady a odkazy na užitečné zdroje (např. Ali \& Gatiti, 2020; Asif \& K. Singh, 2020; Martzoukou, 2020), přehledové články (Tammaro, 2020) či různé kazuistiky (např. Goddard, 2020; Rafiq et al., 2021; Pauwels et al., 2021; Solis \& Kear, 2020 nebo Carbery et al., 2020), část článků přinesla přímo výsledky výzkumu. Nejčastěji použitou metodou byla analýza obsahu webových stránek vybrané skupiny knihoven, např. Guo (2020) se zabýval čínskými akademickými knihovnami, Temiz (2020) knihovnami ve Švédsku, webové stránky amerických knihoven zkoumali Wang (2020) a Yu (2020), který se zaměřil specificky na lékařské knihovny. Na základě dotazníků a rozhovorů byla popsána situace ve Finsku (Haasio \& Kannasto, 2020), dotazníky využil také Hunt (2020) v australských lékařských knihovnách a Zhou (2021). Poslední specifickou skupinu představují studie zaměřené na využití sociálních sítí knihovnami, a to jak kvalitativní (Alajmi \& Albudaiwi, 2020), tak kvantitativní (Gmiterek, 2021).

Ačkoliv již dříve byla zkoumána reakce knihoven na různé neočekávané události, zejména přírodní katastrofy, rozsah pandemie a sním spojený dopad na činnost knihoven na celém světě je bezprecedentní. Témata, kterými se autoři studií zabývají, a jejich zjištění se tedy poměrně značně shodují bez ohledu na zemi původu.

Vzhledem k tomu, že ve všech zemích, v nichž proběhly výše zmíněné studie, byly knihovny po nějakou dobu uzavřeny, je zmiňován především rozvoj digitálních služeb a zprostředkování digitálního obsahu. Knihovny zaznamenaly velký nárůst využívání e-knih a dalších digitálních dokumentů, např̀. Goddard (2020) uvádí 52\% nárůst e-výpůjček, a dvoj- až trojnásobný počet nových uživatelů platformy pro půjčování e-knih, také Tammaro (2020) hovoří o více než 100\% nárůstu užívanosti vybraných digitálních knihoven. Za důležitou roli knihoven bylo považováno zprostř̌edkování důvěryhodných a kvalitních zdrojů o onemocnění Covid-19, nebot' se celosvětově širrila celá řada nepodložených 
informací a „fake news“ (Bangani, 2021; Rafiq et al., 2021; Solis \& Kear, 2020; Yu \& Mani, 2020). Z průzkumu Haasia a Kannasty vyplývá, že 45,2 \% oslovených finských knihoven zavedlo alespoň nějaké nové formy služeb, mezi něž patří např. virtuální referenční služby, které zmiňují i další autoři (Ortega-Martínez et al., 2021; Rafiq et al., 2021), virtuální čtenářské kluby, knihovní podcasty apod.

Významným tématem bylo také online vzdělávání, u akademických knihoven se jednalo zejména o podporu online výuky, ale i o vlastní kurzy informační gramotnosti (Carbery et al., 2020; Rafiq et al., 2021; Zhou, 2021; Pauwels et al., 2021), ale i jiné knihovny převedly své vzdělávací akce do online prostředí (Carbery et al., 2020; Goddard, 2020).

Studie také zmiňují snahu knihoven plnit i nadále komunitní roli a podporovat svoji komunitu, např. formou zesílení wi-fi signálu tak, aby se v okolí budovy mohli připojit ti, kteří by jinak zůstali bez možnosti přístupu k internetu (Goddard, 2020), ale především zintenzivněním online komunikace a interakce s uživateli (Carbery, 2020), podpoře komunitní resilience prostřednictvím sociálních médií (Alajmi \& Albudaiwi, 2020). Ortega-Martinez (2021) hovoří dokonce o empatii knihovníků, doprovázení komunity v obtížné době, o roli knihovníků ve snižování stresu.

Uzavření knihoven mělo také nemalý dopad na jejich zaměstnance, pracovním podmínkám knihovníků v době pandemie se věnuje především Hunt (2020), který popisuje řadu motivačních strategií využívaných vedením knihoven k podpoře zaměstnanců. Naproti tomu Haasio a Kannasto (2020) zmiňují negativní dopady pandemie, jako je nucená dovolená, ale i nerovnost mezi zaměstnanci v rámci knihovny, kdy práci z domova mohli využívat pouze někteří, a nerovnost mezi různými knihovnami. Téma nerovnosti knihoven na bohatém severu a chudém jihu Itálie uvádí i Tammaro (2020), rovněž hovoří o negativních dopadech na externí pracovníky knihoven, kteří jsou kvůli chronickému podfinancování v italských knihovnách často využíváni. Hrozba finančních škrtů se kupodivu objevuje i u finských knihoven (Haasio \& Kannasto, 2020).

V češtině je v databázi KKL pod heslem koronaviry indexováno více než 60 dokumentů, knihovnám v koronaviru bylo věnováno několik tematických sekcí v časopise Čtenář, po jarní vlně byla uspořádána akce CovidCON (Pilniková, 2020). Většina článků se zaměřuje na popis situace jednotlivých knihoven nebo regionů, at' už v jarní vlně (např. Bodorová, 2020; Neubauerová, 2020; Kučerová et al., 2020 aj.) či podzimní vlně (Bednářová, 2020; Brezovic, 2020; Liška, 2020; Staňková, 2020), autoři pojednávají o změnách ve službách, zavádění nových služeb, i dopadu na rozpočty knihoven. Také se věnují zapojení knihoven do boje proti koronaviru např. formou využití 3D tisku (Hyblerová Trachtová, 2020), nebo zapojení do projektu Folding@Home (Fabián, 2020). Knihovna Ostravské univerzity uskutečnila dvě dotazníková šetření (Hradil, 2020; Hradil, 2021) zaměřená na uživatele, v prvním kole byli osloveni studenti, v druhém studenti i akademici, otázky byly směřovány na využívání různých elektronických zdrojů, i na dopady uzavření knihovny na studium. Nárůst využívání e-knih přes platformu Palmknihy 
v době jarního uzavření knihoven ilustrují statistiky publikované Štěchem (2020). Graf v článku ukazuje nárůst výpůjček až na 204 \% v průběhu března.

Dvě studie se zaměřily na knihovníky a jejich situaci v době pandemie. Pracovní podmínky v knihovnách zkoumala Buchtová a kol. (Buchtová et al., 2020). Jejich výzkum ukázal, že home-office v knihovnách je možný, 74 \% respondentů uvedlo, že v době uzavření jim zaměstnavatel umožnil práci z domova. Dále bylo zjištěno, že alespoň část respondentů měla možnost využít tento čas pro sebevzdělávání, a krizová situace také podle výzkumu neměla prakticky dopad na vztahy na pracovišti. Rösslerová (2021) se pak zabývá dopadem sociální izolace knihovníků na jejich volnočasové činnosti, zejména četbu.

\section{Metody}

Pro získání dat byly využity dvě metody, a sice polostrukturované rozhovory s knihovníky vybraných knihoven a analýza vládních dokumentů a archivu konference Knihovna.

Úkol provést rozhovor ve vybrané knihovně na téma: “Jak se proměnily služby knihoven v důsledku epidemiologických opatření - srovnání na jaře a na podzim 2020" dostali studenti v rámci předmětu Knihovnické procesy a technologie vyučovaném na ÚISK pod vedením Barbory Drobíkové. Vyučující určila studentům a studentkám pouze typy knihoven, v nichž mají rozhovor provést. Samotné knihovny si již studující volili dle svých preferencí, bydliště apod. Bylo zřejmé, že není vzhledem k nevelkému počtu studentů $\mathrm{v}$ ročníku možné provést rozhovory $\mathrm{v}$ jistém reprezentativním vzorku různých typů knihoven, nebylo ani cílem zcela přesně pokrýt všechny typy knihoven. Limitující faktory pro provedení studie přinesla také samotná pandemická situace. Jednak byla omezena možnost cestovat a scházet se pro samotné studenty. To platilo často i pro oslovené knihovny, které se pak nemohly výzkumu účastnit jak z důvodu vzdálenosti, tak i z důvodů často nejrůznějších technických omezení. Přesto se nakonec v průběhu listopadu a prosince 2020 podařilo uskutečnit 32 rozhovorů v jak velmi malých obecních knihovnách, tak i větších městských či krajských. Zastoupeny byly též knihovny vysokoškolské, ústavů AV ČR, nechyběly rozhovory v Národní knihovně a Národní technické knihovně. Výsledná různorodost byla velmi inspirativní pro studenty, kteří výsledky navzájem prezentovali v rámci distanční výuky.

Pro provedení výzkumného rozhovoru byla formulována hlavní výzkumná otázka:

Jak se proměnily služby knihoven $v$ důsledku epidemiologických opatření ve srovnání na jaře a na podzim?

Formulovány byly též dva podcíle:

- je předpoklad, že změna bude trvalá nebo jsou to změny dočasné?

- jsou to změny, které knihovny posunují a knihovny tak zlepšují své služby nebo naopak knihovna ztrácí jedno ze svých poslání? 
Rozhovory byly rozděleny do určitých celků týkajících se:

- Služeb knihoven nad zdroji - fyzické fondy

- Služeb knihoven nad zdroji - digitální a elektronické fondy

- Vzdělávací činnosti a celoživotního vzdělávání

- Knihoven jako prostoru a komunitní role knihovny

- Propagace služeb knihovny, marketing

- Nových výzev, služeb apod.

Studující předmětu Knihovnické procesy a technologie měli za úkol si zvolit k rozhovoru zástupce konkrétní knihovny, která spadala do níže uvedených kategorií. Aby studující byli nuceni využít širší škály typů knihoven, vyučující určila vždy na daný typ knihovny max. možné množství rozhovorů.

Výsledkům rozhovorů předchází stručný přehled vývoje protiepidemických opatření ve vztahu ke knihovnám od 1. 3. do 31. 12. 2020, který byl sestaven na základě analýzy dokumentů vlády ČR a Ministerstva zdravotnictví a archivu konference. Chronologicky řazený soupis relevantních dokumentů je uveden v prŕloze.

\section{Přehled protiepidemických opatření týkajících se knihoven v průběhu roku 2020}

První př́pady nákazy koronavirem v České republice byly potvrzeny 1.3.2020, od 11.3. byly uzavřeny všechny stupně škol, 12.3. vláda vyhlásila nouzový stav a od 14. 3. rozhodla o zákazu maloobchodního prodeje a služeb, který se týkal i knihoven. Od 16. 3. byl navíc omezen i volný pohyb osob. Všechna opatření měla omezenou platnost, ale s postupujícím se rozvojem nákazy byla prodlužována, teprve v druhé polovině dubna se začalo jednat o možném uvolňování opatření. Opětovné otevření knihoven bylo umožněno usnesením vlády ze dne 23.4., a sice od 27.4. za dodržení následujících pravidel:

- zajistit, aby pracovníci knihoven nosili rukavice při kontaktu s knihami a dalším podobným zbožím,

- $\quad$ u vstupu do knihovny zákazník provede dezinfekci rukou, přičemž dezinfekční prostředek zajistí provozovatel knihovny.

Ministerstvo kultury vydalo k otevření knihoven doporučení, v němž specifikovalo zejména hygienická pravidla, která by návštěvníci měli dodržet. Podle zprávy Víta Richtera v konferenci Knihovna se k 30. 4. v některých krajích procento otevřených knihoven pohybovalo již mezi 70 a 80, od 4. 5. se pak chystala otevř́t většina knihoven. 
V průběhu května a června docházelo $\mathrm{k}$ dalšímu uvolňování, opět bylo možné pořádat akce při dodržení maximálního předepsaného počtu účastníků, od 1. 7. pak byla zrušena až na výjimky povinnost nosit roušky. V letních měsících byla epidemická situace klidná a žádná celoplošná opatření se nezaváděla, v druhé polovině srpna se však situace začala zhoršovat a vláda byla nucena opět přistoupit nejprve k zavedení povinného nošení ochranných prostředků dýchacích cest (od 10.9.), a posléze postupně i k omezování různých oblastí. Pro knihovny to zatím znamenalo od 19. 9. pouze návrat hygienických opatření (zajistit, aby pracovníci knihoven prováděli hygienu rukou se zvýšenou frekvencí při kontaktu s knihami a dalším podobným zbožím, u vstupu do knihovny zákazník provede dezinfekci rukou, přičemž dezinfekční prostředek zajistí provozovatel knihovny). Od 5. 10. byl však opět vyhlášen nouzový stav a bylo omezeno konání hromadných akcí, se zhoršující se epidemickou situací byla opatření postupně zpřísňována. Ještě 8. 10. tehdejší ministr zdravotnictví Roman Prymula v interview pro ČT mimo jiné řekl, že provoz knihoven a knihkupectví nebude omezen, ale již od 22. 10. byl opět omezen volný pohyb osob a vstoupil v platnost zákaz maloobchodního prodeje a služeb, který opět platil i pro knihovny. Podle sdělení Víta Richtera v konferenci Knihovna neměly knihovny ani výjimku pro provozování „výdejního okénka“. Další úpravu opatření, která se knihoven dotkla, přineslo zavedení Protiepidemického systému (PES) od 16. 11., který specifikoval opatření v různých oblastech společnosti včetně knihoven v návaznosti na index rizika vyjadřující stav epidemie. PES měl vnést do opatř̌ení přehlednost, závazná však byla i nadále pouze př́islušná nařízení vlády.

\section{Tabulka 1. Opatření týkající se knihoven podle PES}

\begin{tabular}{|l|l|}
\hline 5 & $\begin{array}{l}\text { Pouze výdej předem objednaných výpůjček a jejich vracení přes výdejní okénko nebo } \\
\text { u vyhrazeného pultu co nejblíže vchodu do knihovny, s tím, že případná fronta se tvoří vně } \\
\text { knihovny (v původní verzi pouze bezkontaktní výdej a vracení výpůjček). }\end{array}$ \\
\hline 4 & $\begin{array}{l}\text { Pouze výdej predem objednaných výpůjček a jejich vracení přes výdejní okénko nebo } \\
\text { u vyhrazeného pultu co nejblíže vchodu do knihovny, s tím, že případná fronta se tvoří vně } \\
\text { knihovny (v původní verzi pouze výdej předem objednaných výpůjček a jejich vracení přes } \\
\text { výdejní okénko). }\end{array}$ \\
\hline 3 & $\begin{array}{l}\text { Omezení počtu osob (10soba na } 15 \mathrm{~m} 2 \text { provozní plochy), rozestupy } 2 \text { m mezi zákazníky, } \\
\text { režimová a organizační opatření. }\end{array}$ \\
\hline 2 & $\begin{array}{l}\text { Omezení počtu osob (2 osoby na 15m2provozní plochy), rozestupy } 2 \text { m mezi zákazníky, } \\
\text { organizační a režimová opatření. }\end{array}$ \\
\hline 1 & $\begin{array}{l}\text { Omezení počtu osob (4 osoby na 15m2provozní plochy), rozestupy } 2 \text { m mezi zákazníky, } \\
\text { organizační a režimová opatření. }\end{array}$ \\
\hline
\end{tabular}


Od 23. 11. byl umožněn výdej objednaných knih prostřednictvím „výdejního okénka“, počínaje 3. 12. byly knihovny opět přístupné při dodržení limitu osob, ale už od 18. 12. se vrátilo pouze okénko a do konce roku se situace již nezměnila.

\section{Výsledky rozhovorů}

Celkem bylo provedeno 32 rozhovorů v různých typech knihoven (viz. Tab. 2). Rozhovory probíhaly na podzim 2020, zahrnují tedy popis situace na jaře a na podzim 2020.

Tabulka 2. Přehled provedených rozhovorů

\begin{tabular}{|l|l|}
\hline Typ knihovny & Počet rozhovorů \\
\hline V obci do 500 obyvatel & 2 \\
\hline V obci s 1 001-3 000 obyvateli & 2 \\
\hline V obci s 3 001-5 000 obyvateli & 2 \\
\hline V obci s 5 001-10 000 obyvateli & 2 \\
\hline V obci s 10 001-20 000 obyvateli & 2 \\
\hline V obci s 20 001 - 40 000 obyvateli & 2 \\
\hline Fakultní knihovny - v rámci univerzit & 8 \\
\hline Centrální univerzitní knihovny & 3 \\
\hline Krajské knihovny & 2 \\
\hline Knihovny ústavů AV ČR & 2 \\
\hline Knihovna AV Č́R & 1 \\
\hline Národní knihovna ČR & 2 \\
\hline Národní technická knihovna & 1 \\
\hline
\end{tabular}

Výsledky jsou uspořádány podle tematických celků, které se v rozhovorech objevily, kromě okruhů daných strukturou rozhovoru to byla i témata, které souvisela se všemi okruhy, např. komentáře $\mathrm{k}$ provozu. 


\section{Provoz}

Stejně jako v jiných oblastech služeb, i pro knihovny znamenalo jarní uzavření šok, následné rozvolňování pak především chaos a rychlé změny, kdy bylo třeba improvizovat především ve výpůjčních službách, protiepidemická opatření se ve velkém dotkla také pořádání vzdělávacích a komunitních akcí. Na podzim již byly knihovny více připraveny, i když nejasnosti ve výkladu opatření někdy přetrvávaly, částečné zpřehlednění pak přinesl již zmiňovaný PES.

Větší knihovny se musely vyrovnat s potřebou jiné organizace práce, především organizace „,nepotkávání se“ na pracovišti, takže se vytvářely týmy, ti, co mohli pracovat z domova, zůstávali na „home office“. Součástí práce z domova bylo někde i povinné vzdělávání. V některých knihovnách práce z domova umožněna nebyla, nebo se netýkala všech kategorií pracovníků, což nebylo vždy pozitivně přijímáno. Pro některé pracovníky znamenal změněný režim naopak delší pracovní dobu, jedna účastnice zmínila množství e-mailů, které dostávala v každou denní dobu. Bylo také třeba najít náhradní činnosti, které obvykle zahrnovaly inventury, revize, odpisy a úklid.

\section{Výpůjční služby}

Výpůjční služby byly protiepidemickými opatřeními postiženy nejvíce, po úplné uzávěře následovalo částečné uvolnění, se kterým se knihovny vyrovnávaly podle svých prostorových a personálních možností. Na jaře měli uživatelé do knihoven po uvolnění přístup, na podzim to bylo především formou „výdejního okénka“, tj. výdeje předem objednaných knih (v jednom př́ípadě nazývaných balíčky). Lépe vybavené knihovny mohly použít self-check, specifická situace byla u interních uživatelů v knihovnách ústavů AV ČR, které jsou natolik považovány za součást pracoviště, že výpůjční služby omezily pouze pro externí uživatele.

S výdejem objednaných knih souvisel nárůst objednávek a rezervací, ale celkově z rozhovorů vyplývalo, že počet výpůjček byl nižší, nutnost vybrat si knihu z katalogu namísto ve volném výběru čtenáře odrazovala. Jak to vyjádřila jedna z účastnic výzkumu: „...to puojčování přes okýnko některé čtenáře odradilo. Většina sem chodí s tím úmyslem. Vejdou do knihovny, rádi se rozhližejí a vybírají očima, př́ípadně si nechají doporučit. Takže ta nutnost objednání odrazovala a odrazuje nadále.“ $\mathrm{V}$ některých knihovnách bylo třeba zavést možnost objednávky z volného výběru, v akademických knihovnách docházelo i ke změnám statusů u prezenčních exemplárů kvůli uzavření studoven. Tyto změny byly však vesměs považovány za dočasné, vázané pouze na mimořádnou situaci, pouze $\mathrm{v}$ jednom případě bylo zmíněno, že přísně prezenční fond bude omezen i po skončení pandemie.

Některé knihovny již před pandemií poskytovaly rozvážkovou službu nap̌r. pro seniory, některé tuto službu nově zavedly nebo o ní začaly uvažovat. Jeden respondent zmínil rozpor mezi stanoviskem SKIP a Národní knihovny, která rozvážku nedoporučovala, a hygienické stanice, která v ní nespatřovala problém. 
Pro návrat knih na mnoha místech sloužily biblioboxy nebo návratové automaty, na jaře však nakládání s knihami komplikovala doporučená karanténa, případně dezinfekce. Karanténa zdržovala návrat knih do oběhu, v jedné knihovně dokonce zvýšila zátěž knihovnic, nebot' „dávali jsme knihy do karantény a nemáme výtahy a poté, když je zakládáte, potom príide nová várka a nemáme dost místa, tak když šestkrát vyběhnete schody, tak to bylo náročné."

\section{E-zdroje}

V oblasti elektronických zdrojů se zřetelně odlišovaly knihovny vysokoškolské a akademické. V těchto typech knihoven je přístup k elektronickým zdrojům i za normálních podmínek mnohem širší a uživatelé jsou zvyklí je využívat, i když jak z rozhovorů vyplynulo, dostupnost a využívanost e-zdrojů je velmi ovlivněna zaměřením knihovny a jejích uživatelů. $\mathrm{V}$ technických a přírodních vědách uživatelé prakticky nezaznamenali problém, nebot' literaturu v elektronické podobě byli zvyklí používat už před pandemií. V humanitních a společenských vědách a v umění se naopak ukázalo, že zdrojů, at' už e-knih či databází, není vždy dostatek, případně uživatelé preferují tištěné zdroje. Knihovnice z lékařské fakulty k tomu poznamenala, že ,elektronické zdroje nejsou úplně nakloněné studiu, např́klad anatomický atlas, histologické atlasy a tak, to je pořád lepši číst z knižky.“ Na jaře měly akademické knihovny také množství nabídek zkušebních přístupů, k akvizici nových zdrojů na jejich základě však př́liš nedocházelo.

Samostatné téma představuje Národní digitální knihovna - Covid. Mnohokrát byl zejména v akademických knihovnách zmiňován přínos zpřístupnění digitalizovaných fondů pro studenty a pedagogy a opakovaně zaznívala potřeba uchovat tento př́istup i do budoucna.

Pro ostatní knihovny znamenají e-zdroje převážně jen e-knihy. Větší knihovny poskytují svým čtenářům možnost vypůjčit si e-knihy prostřednictvím služby eReading (Palmknihy), která je však pro knihovny, jak v jednom z rozhovorů zaznělo, poměrně drahá. $Z$ toho plyne, že menší knihovny si ji nemohou dovolit, a tak svoje čtenáře odkazovaly alespoň na e-knihy dostupné zdarma prostřednictvím Městské knihovny v Praze. Ačkoliv by se dalo předpokládat, že počet e-výpůjček vzroste, ne všude se to potvrdilo, některé knihovny skutečně nárůst e-výpůjček zaznamenaly, jinde počet stagnoval.

\section{Komunitní role}

Jeden z okruhů otázek se také týkal komunitní role knihoven v pandemii. Opět se zde projevily rozdíly mezi akademickými a ostatními knihovnami. Pro veřejné knihovny je komunitní role významná, pořádají akce pro různé cílové skupiny, jsou místem setkávání. Protiepidemická opatření tyto aktivity nejprve zcela znemožnila, poté výrazně omezila, a ačkoliv knihovny v letním období některé akce pořádaly, návštěvnost byla omezená, lidé se obávali nákazy. Některé knihovny přesunuly část svých aktivit do online prostředí, snažily se organizovat napřr. různé internetové soutěže či kvízy, kontaktovat 
seniory nebo připravit aktivity mimo prostory knihovny za dodržení hygienických opatření (např. adventní stezka).

Většina akademických knihoven komunitní roli nepovažuje za důležitou součást svého poslání, ale není to pravidlem a záleží na úhlu pohledu na komunitu. Některé akademické knihovny se na komunitu dívají i jako na společenství lidí sdílejících stejný profesní zájem, nejen ve smyslu místního společenství, a tudíž svoji komunitní roli spatřují v podpoře komunity studentů a vyučujících. I v akademických knihovnách však byla tato podpora omezená.

Na tom, že komunitní role byla pandemií výrazně omezena, ne-li zcela znemožněna, se tedy shodli prakticky všichni účastníci výzkumu.

\section{Vzdělávání}

Také vzdělávací akce, at' už pro veřejnost či pro knihovníky, byly pandemií limitovány, více však u nich došlo $\mathrm{k}$ přesunu do online prostředí, v mîre závislé především na personálních možnostech knihovny. Některé knihovny přesunuly veškeré akce online, některé pouze vybrané, ty, u nichž to vzhledem k povaze akce mělo smysl. Přechod na online vzdělávání s sebou přinesl nutnost nejen se obeznámit s novými nástroji, napřr. zvládnout tvorbu videí či naučit se používat aplikace pro online setkávání, ale i přizpůsobit obsah vzdělávání či ztratit ostych před kamerou. Online prostředí s sebou přineslo také nové hrozby, jeden účastník př́imo zmínil cílené narušení webináře, knihovny musely stanovovat pravidla pro online prostředí. Zatímco respondenti z veřejných knihoven spîše zmiňovali menší zájem uživatelů o online vzdělávací akce vzhledem k různým technickým i psychologickým bariérám, u větších akademických knihoven došlo k nárůstu zájmu, zvětšení dosahu. Akademické knihovny se také často podílely na podpoře distanční výuky na svých univerzitách, protože často již měly zkušenost s podporou e-learningu, např. ve formě tvorby kurzů v Moodle, a mohly tedy tyto zkušenosti předat vyučujícím.

Se vzděláváním byly spojené určité přínosy, které účastníci výzkumu v pandemii spatřovali. Jednak to byla možnost využít práci z domova k vlastnímu vzdělávání, dále také možnost jednou vytvořený vzdělávací obsah uchovat a znovu použít, zmiňován byl i větší dosah akcí, a na rozdíl od výpůjčních služeb v oblasti vzdělávání hodlají knihovny některé změny zachovat, nap̌r. více využívat kombinace prezenčního a online vzdělávání.

\section{Propagace}

Omezení kontaktu s uživateli přinutilo knihovny také přizpůsobit strategie propagace a informování o dění v knihovně. Bylo třeba přemýšlet o nové strategii, jak dát lidem vědět ,že knihovna je stále tady“. I zde se knihovny více přesunuly do online prostředí, změny spočívaly např. ve vytvoření nových profilů na Facebooku nebo Instagramu, oslovení čtenářů hromadnými e-maily či newsletter. Ne zcela výjimečně však účastníci výzkumu uváděli, že k žádným výrazným změnám nedošlo, bud’ proto, že již 
před pandemií využívali prakticky všechny dostupné kanály propagace, nebo naopak na změnu nebyly síly, zejména u těch nejmenších knihoven.

\section{Př́nosy}

Pandemie přinesla výrazné omezení ve všech sférách života, v rámci rozhovorů však byla zmiňována i pozitiva. Zejména se projevila důležitost knihoven, mnohdy nepostradatelnost, zájem čtenářu (pro ilustraci viz. Tab. 3).

\section{Tabulka 3. Úryvky z rozhovorů na téma nepostradatelnost knihoven}

$V$ podstatě nás překvapilo, jak lidem chybí zavřená knihovna. Možná někomu víc než zavřený supermarket? Ta potřeba čtení jako u některých lidí je velká.

Tak plus by byla určitě v tom, co jsi říkala, že pokud ti lidé si uvědomí, že ted’ko jim to vlastně hrozně chybí, že se nemají kde setkat, že ta knihovna pro ně byla takovým místem, které možná brali jako takovou samožrejmost. Ani o tom nepremýšleli, že se tam zastaví nebo že tam jdou na nějakou tu akci, že se tam s někým potkají, tak zjistili, že ted’ najednou to nejde a že opravdu jim to chybí. A to by tedy mohlo pomoci tomu, že by o ty služby byl skutečně třeba i větší zájem.

Já v tom vidím velké plus, protože se ukázalo, že ti čtenáři pořád tu knihovnu potřebují. Opravdu jsem nečekala tak velký...Spoustu lidí, co si prodlužují knihy, tak nám píšou, že už se těší, až zase otevřeme.

Já si myslím, že jako určitě pro nás bylo hrozně hezký to, jak lidi reagují na zavření knihovny a potom na znovuotevření knihovny, že jsme se přesvědčili o tom, že pro ně ta služba opravdu smysl má. Je to asi opravdu nedílná součást jejich života, protože ty lidi potkáváte po městě: a kdy už otevřete, už jako a my můžeme prijít.

Myslím si, že konečně svět viděl, respektive česká společnost viděla, že knihovníci jsou taky schopní lidé.

A já bych byla ráda, kdyby se ukázalo, že knihovny... a myslím, že se to i ukázalo, že knihovny mají stále co nabizet $i$ v té nové době. 
Že si umí poradit, že jsou i kreativní a že jsou prostě dưležité. Takže výzva je v tom, aby knihovny byly dost sebevědomé a aby si v tom věrily, že skutečně jsou platné, když jsou třeba zavřené, když to řeknu takhle.

Já bych byla hodně ráda, kdyby jí to posililo, myslím, že nám hodně čtenářu dává najevo, že jim chybí, že pro ně není dobré, když je knihovna zavřená, už vlastně jen to jak se zásobili během celého října, když se předpřipravovali na zavření a byli i zklamaní ze zrušených akcí.

Myslím, že se ukázalo, že je důležité, aby knihovny tyto služby poskytovaly, že se více lidí dozvědělo, že je knihovny poskytuji a někteři možná zjistili, že není až třeba úplně tak nekomfortní je využivat. Takže tady si myslím, že by to mohlo napomoci k jejich dalšimu rozvoji a možná trošičku $i$ - pokud jde o advokacii v tom získávání zdrojů - aby knihovny vůbec tyto služby poskytovat mohly, protože to není vždycky levná záležitost. Takže tam si myslím, že by to mohlo rozvoji těch služeb pomoci.

Několikrát byla také zmíněna změna uvažování, která vedla $\mathrm{k}$ přehodnocení některých procesů a k trvalým změnám, také rozvoj digitálních služeb či ověření reakce a adaptace na krizovou situaci. 


\section{Shrnutí a závěry}

Z přehledu protiepidemických opatření je vidět, že situace se poměrně často měnila a knihovny se musely této situaci přizpůsobovat, na jaře to byla situace zcela nová, doporučená opatření a stanoviska hygienických služeb v regionech nebyla často zcela jednotná (např. dezinfekce knih, př́ípadně jejich umistování do karantény, př́stup k roznášce knih). Na podzim byly již knihovny lépe připraveny, ale i toto období bylo náročné. Stejně jako v zahraničí i u českých knihoven s výjimkou těch nejmenších docházelo většinou k nárůstu využívání elektronických zdrojů, část akcí se přenesla do online prostředí a opět především větší knihovny zintenzivnily komunikaci na sociálních sítích. Ačkoliv pandemie měla celou řadu negativních dopadů, účastníci výzkumu v nastalé situaci spatřovali i pozitiva, zejména to, že knihovny prokázaly svoji potřebnost, ale i impuls k zavedení nových služeb a přehodnocení těch existujících.

Př́spěvek představuje dílčí kvalitativní sondu do situace knihoven v uplynulém roce, popsaná skutečnost koresponduje i s ostatními již publikovanými zjištěními, pro celkové zhodnocení dopadů pandemie však budou třeba rozsáhlejší šetření.

Autorky článku by rády poděkovaly všem studentům a studentkám, které uskutečnily rozhovory, z nichž tento článek čerpá. Jmenovitě jsou to (dle abecedy):

Jana Bednářová, Markéta Beštová, Veronika Borovková, Filip Čihula, Nikola Doleželová, Eliška Flejberková, Eliška Goldschmidová, Hanke Havlátů, Zuzana Hejlová, Markéta Heriánová, Josef Chotívka, Lenka Kalousová, Lenka Kiková, Aneta Kiliánková, Kateřina Krohová, Lenka Kroupová, Markéta Kurešová, Nikola Lásková, Sára Lepší, Jakub Motl, Prokop Myslivec, Libuše Padalíková, Matouš Pánek, Monika Petříčková, Pham My Hanh, Ondřej Průša, Jan Skopal, Iveta Radkovová, Lucie Řadová, Barbora Šantorová, Natálie Šnaiberková, Denisa Šourková, Zuzana Vejškrabová, Barbora Zuščíková

Výzkum byl podpořen z programu Univerzity Karlovy Progres Q15 „Životní dráhy, životní styly a kvalita života z pohledu individuální adaptace a vztahu aktérů a instituci“. 


\section{Použitá literatura}

Alajmi, B., \& Albudaiwi, D. (2020). Response to COVID-19 Pandemic: Where Do Public Libraries Stand?. Public Library Quarterly, 1-17. https://doi.org/10.1080/01616846.2020.1827618

Ali, M., \& Gatiti, P. (2020). The COVID-19 (Coronavirus) pandemic: reflections on the roles of librarians and information professionals. Health Information \& Libraries Journal, 37(2), 158-162. https://doi.org/10.1111/hir.12307

Asif, M., \& K. Singh, K. (2020). Trends, opportunities and scope of libraries during Covid-19 pandemic. IP Indian Journal of Library Science and Information Technology, 5(1), 24-27. https://doi.org/10.18231/j.ijlsit.2020.005

Bangani, S. (2021). The fake news wave: Academic libraries' battle against misinformation during COVID-19. The Journal of Academic Librarianship, 47(5).

https://doi.org/10.1016/j.acalib.2021.102390

Bednářová, J. (2020). Knihovny Ústeckého kraje a koronavirus. Čtenář: měsičník pro knihovny, 72(12), 429-430.

Bodorová, R. (2020). Dobřřšská knihovna v akci - online na webu, FB a instagramu. U nás: knihovnicko-informační zpravodaj Královéhradeckého kraje, 30(2), 14-15. https://www.svkhk.cz/SVKHK/u-nas-pdf_archiv/20200210.pdf

Brezovic, I. (2020). Z kraje Vysočina. Čtenářr: měsíčník pro knihovny, 72(12), 424-425.

Buchtová, B., Horáková, M., \& Nekolová, K. (2020). Jak koronakrize ovlivnila pracovní podmínky v knihovnách. Bulletin SKIP, 29(2). https://bulletinskip.skipcr.cz/node/762

Carbery, A., Fallon, H., Higgins, M., Kennedy, E., Lawton, A., \& McCauley, C. (2020). Irish libraries and COVID-19: first reflections. Insights: the UKSG journal, 33.

https://insights.uksg.org/articles/10.1629/uksg.522/

Fabián, O. (2020). České knihovny a projekt Folding@Home. U nás: knihovnicko-informační zpravodaj Královéhradeckého kraje, 30(2), 42-43. https://www.svkhk.cz/SVKHK/u-naspdf_archiv/20200227.pdf

Gmiterek, G. (2021). Polish university libraries social networking services during the COVID-19 pandemic spring term lockdown. The Journal of Academic Librarianship, 47(3).

https://doi.org/10.1016/j.acalib.2021.102331 
Goddard, J. (2020). Public Libraries Respond to the COVID-19 Pandemic, Creating a New Service Model. Information Technology and Libraries, 39(4). https://doi.org/10.6017/ital.v39i4.12847

Guo, Y., Yang, Z., Yang, Z., Liu, Y., Bielefield, A., \& Tharp, G. (2020). The provision of patron services in Chinese academic libraries responding to the COVID-19 pandemic. Library Hi Tech, --(--). https://doi.org/10.1108/LHT-04-2020-0098

Haasio, A., \& Kannasto, E. (2020). Covid-19 and its impact on Finnish public libraries. Qualitative and Quantitative Methods in Libraries, (2020), 3-19.

http://78.46.229.148/ojs/index.php/qqml/article/view/639

Hradil, J. (2020). Mimořádná opatření s vlivem na úpravy a rozvoj služeb (výsledky dotazníkového šetření). Čtenářr: měsíčník pro knihovny, 72(11), 394-395. https://www.svkk1.cz/ctenar/stahnout$\operatorname{pdf} / 183$

Hradil, J. (2021). Srovnání postojů uživatelů Univerzitní knihovny Ostravské univerzity (druhé kolo dotazníkových šetření). Čtenář: měsičník pro knihovny, 73(4), 128-129.

Hunt, T. (2020). AUSTRALASIAN HEALTH LIBRARIES RESPONSES TO THE COVID-19

PANDEMIC: HLA Survey Results. Journal of Health Information and Libraries Australasia, 1(2), 33-43. https://www.johila.org/index.php/Johila/article/view/21/25

Hyblerová Trachtová, V. (2020). 3D tisk v obraně proti koronaviru. Čtenář: měsíčník pro knihovny, 72(5), 172. https://www.svkkl.cz/ctenar/stahnout-pdf/178

Kučerová, Z., Najmanová, M., Mrvová Krejčová, K., Steinbrecherová, L., Orltová, M., Havlíčková, S., Nedvědová, K., Šímová, M., Vejdělková, E., \& Pešata, J. (2020). Vyznání, aneb, Jak mě a mou práci ovlivnil koronavirus. Čtenár̆: měsíčník pro knihovny, 72(5), 163-167.

https://www.svkkl.cz/ctenar/stahnout-pdf/178

Liška, R. (2020). Pád statistických ukazatelů ve Středočeském kraji. Čtenářr: měsičník pro knihovny, 72(12), 423-424.

Martzoukou, K. (2020). Academic libraries in COVID-19: a renewed mission for digital literacy. Library Management, 42(45), 266-276. https://doi.org/10.1108/LM-09-2020-0131

Neubauerová, S. (2020). Knihovna online, aneb, Zavřené dveře, otevřená okna. U nás: knihovnickoinformační zpravodaj Královéhradeckého kraje, 30(2), 18-20. https://www.svkhk.cz/SVKHK/u-naspdf_archiv/20200212.pdf 
Ortega-Martínez, E., Pacheco-Mendoza, J., García Meléndez, H., Ortiz-Díaz, E., \& SaavedraAlamillas, C. (2021). Digital services adapted by libraries in Mexico to COVID-19 pandemic: a critical review. Digital Library Perspectives, 37(1), 3-17. https://doi.org/10.1108/DLP-07-2020-0063

Pauwels, N., De Meulemeester, A., Romagnoli, A., Buysse, H., \& Peleman, R. (2021). Medical and health informatics services during and after the COVID-19 pandemic should be virtual, tailored, responsive and interactive: a case study in Belgium. Health Information \& Libraries Journal, 38(1), 66-71. https://doi.org/10.1111/hir.12330

Pilniková, M. (2020). CovidCON. Čtenář: měsičník pro knihovny, 72(11), 383-386. https://www.svkkl.cz/ctenar/stahnout-pdf/183

Rafiq, M., Batool, S., Ali, A., \& Ullah, M. (2021). University libraries response to COVID-19 pandemic: A developing country perspective. The Journal of Academic Librarianship, 47(1). https://doi.org/10.1016/j.acalib.2020.102280

Rösslerová, K. (2021). Jak pomoci knihovníkům číst (o dopadech sociální izolace na knihovníky Knihovny FF UK). Čtenář: měsičník pro knihovny, 73(4), 130-131.

S. Pauwels, N., De Meulemeester, A., Romagnoli, A., Buysse, H., \& Peleman, R. (2021). Medical and health informatics services during and after the COVID-19 pandemic should be virtual, tailored, responsive and interactive: a case study in Belgium. Health Information \& Libraries Journal, 38(1), 66-71. https://doi.org/10.1111/hir.12330

Solis, J., \& Kear, R. (2020). Online Activities of Croatian Public Libraries During COVID-19 Spring Lockdown. International Information \& Library Review, 52(4), 318-319.

https://doi.org/10.1080/10572317.2020.1834246

Staňková, M. (2020). Z Libereckého kraje. Čtenář: měsíčník pro knihovny, 72(12), 431.

Štěch, V. (2020). Využívání e-knih v knihovnách v době koronaviru. Bulletin SKIP, 29(1). https://bulletinskip.skipcr.cz/node/729

Tammaro, A. (2020). COVID 19 and Libraries in Italy. International Information \& Library Review, 52(3), 216-220. https://doi.org/10.1080/10572317.2020.1785172

Temiz, S., \& Salelkar, L. (2020). Innovation during crisis: exploring reaction of Swedish university libraries to COVID-19. Digital Library Perspectives, 36(4), 365-375. https://doi.org/10.1108/DLP-052020-0029 
Wang, T., \& Lund, B. (2020). Announcement Information Provided by United States' Public Libraries during the 2020 COVID-19 Pandemic. Public Library Quarterly, 39(4), 283-294.

https://doi.org/10.1080/01616846.2020.1764325

Yu, F., \& Mani, N. (2020). How American Academic Medical/Health Sciences Libraries Responded to the COVID-19 Health Crisis: An Observational Study. Data and Information Management, 4(3), 200-208. https://doi.org/10.2478/dim-2020-0013

Zhou, J. (2021). The role of libraries in distance learning during COVID-19. Information Development. https://doi.org/10.1177/02666669211001502 


\section{Příloha. Chronologický soupis opatření vládních orgánů a dalších relevantních dokumentů}

VČeské republice jsou první tři potvrzené případy nákazy koronavirem. (2020). Ministerstvo zdravotnictví České republiky. Retrieved June 24, 2021, from https://koronavirus.mzcr.cz/v-ceskerepublice-jsou-prvni-tri-potvrzene-pripady-nakazy-koronavirem/

Usnesení vlády České republiky ze dne 12. března 2020 č. 194. (2020).

https://apps.odok.cz/attachment//down/IHOABMNHPBSV

Usnesení vlády České republiky ze dne 14. března 2020 č. 211 o přijetí krizového opatření. (2020). https://apps.odok.cz/attachment/-/down/IHOABMPBJNVK

Usnesení vlády České republiky ze dne 15. března 2020 č. 215 o přijetí krizového opatření. (2020). https://www.vlada.cz/assets/media-centrum/aktualne/Omezeni-pohybu-osob.pdf

Usnesení vlády České republiky ze dne 23. dubna č. 453 o přijetí krizového opatření. (2020). https://www.vlada.cz/assets/media-centrum/aktualne/uv200423-0453-converted.pdf

Zrušení mimořádného opatření [o ochraně dýchacích cest](2020). https://koronavirus.mzcr.cz/wpcontent/uploads/2020/06/Zru\%C5\%A1en\%C3\%AD-mimo\%C5\%99\%C3\%A1dn\%C3\%A9hoopat\%C5\%99en\%C3\%AD-ze-dne-1.-6.-2020-k-no\%C5\%A1en\%C3\%AD-ochrann\%C3\%BDchprost $\% \mathrm{C} 5 \% 99 \mathrm{edk} \% \mathrm{C} 5 \% \mathrm{AF}-\mathrm{d} \% \mathrm{C} 3 \% \mathrm{BDchac} \% \mathrm{C} 3 \% \mathrm{ADch}-\mathrm{cest}-\mathrm{s}-$ \%C3\%BA\%C4\%8Dinnost\%C3\%AD-od-1.-7.-2020.pdf

ZÁKLADNÍ DOPORUČENÍ Ministerstva kultury a Ministerstva zdravotnictví PRO OTEVÍRAJÍCÍ SE KNIHOVNY. (2020). Ministerstvo kultury. Retrieved June 24, 2021, from https://www.mkcr.cz/novinky-a-media/zakladni-doporuceni-ministerstva-kultury-a-ministerstvazdravotnictvi-pro-otevirajici-se-knihovny-4-cs3753.html

Richter, V. (2020, April 30). Stav otevření knihoven k 30. 4. 2020. https://1sv.cesnet.cz/cgi-

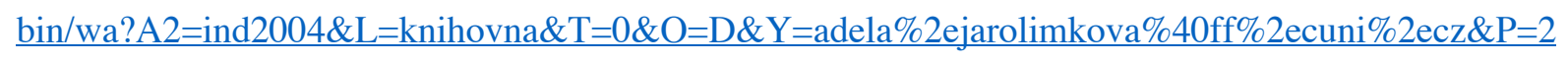
$\underline{6777 \& X=69752495 \mathrm{EBCD} 666610}$

Mimořádné opatření [nošení ochranných prostředků dýchacích cest s výjimkami s účinností od 10.9.2020 do odvolání](2020). https://www.mzcr.cz/wp-content/uploads/2020/09/Mimoradneopatreni-noseni-ochrannych-prostredku-dychacich-cest-s-vyjimkami-s-ucinnosti-od-10-9-2020-doodvolani.pdf 
Mimořádné opatření [omezení provozoven a provozu služeb s účinností od 19.9.2020 do odvolání](2020). https://www.mzcr.cz/wp-content/uploads/2020/09/Mimoradne-opatreni-omezeniprovozoven-a-provozu-sluzeb-s-ucinnosti-od-19-9-2020-do-odvolani.pdf

Usnesení vlády České republiky ze dne 30. záři 2020 č. 957. (2020). https://apps.odok.cz/attachment//down/IHOABTXK4WF6

Usnesení vlády České republiky ze dne 30. záři 2020 č. 958. (2020). https://apps.odok.cz/attachment//down/IHOABTXK4Y1T

Je obrovská propast mezi vnímáním epidemie u lidí do 35 let a u starších. Mladí nechtějí ztrácet svobodu a brání se restrikcím, říká Prymula. (2020). Česká televize. Retrieved June 24, 2021, from https://ct24.ceskatelevize.cz/specialy/koronavirus/3202319-zive-ministr-zdravotnictvi-romanprymula-komentuje-opatreni-v-interview

Usnesení vlády České republiky ze dne 21.října 2020 č. 1078 o přijetí krizového opatrení. (2020). https://www.vlada.cz/assets/media-centrum/aktualne/Pohyb-osob-1078.pdf

Usnesení vlády České republiky ze dne 21.října 2020 č. 1079 o přijetí krizového opatření. (2020). https://www.vlada.cz/assets/media-centrum/aktualne/Omezeni-obchodu-a-sluzeb-1079.pdf

Richter, V. (2020). Půjčování v době nouzového stavu. https://lsv.cesnet.cz/cgibin/wa?A2=ind2010\&L=knihovna\&T=0\&O=D\&X=AAEF6B6BC8FE71 A86D\&Y=adela.jarolimkova $\% 40 f f . c u n i . c z \& P=27561$

Epidemiologickou situaci bude nově znázorňovat systém hodnocení PES. Ministerstvo zdravotnictví České republiky. Retrieved June 24, 2021, from https://koronavirus.mzcr.cz/epidemiologickou-situacibude-nove-znazornovat-system-hodnoceni-pes/

Matice opatření - kultura, bohoslužby. Ministerstvo zdravotnictví České republiky. Retrieved June 24, 2021, from https://koronavirus.mzcr.cz/wpcontent/uploads/2020/11/Matice opatreni PES druheho stupne kultura bohosluzby final 29112020 . .pdf 


\section{Poznámka o autorech}

\section{Adéla Jarolímková}

Původně rešeršérka v lékařských knihovnách, nyní odborná asistentka a od roku 2019 ředitelka ÚISK FF UK.

E-mail: adela.jarolimkova@ff.cuni.cz

\section{Barbora Drobíková}

Správkyně centrálního knihovnicko-informačního systému Univerzity Karlovy a odborná asistentka ÚISK FF UK, v letech 2012-2019 ředitelka ÚISK.

E-mail: barbora.drobikova@ff.cuni.cz 